\title{
Study On Microbiological Profile of Endotracheal Secretions in Patients on Mechanic Ventilators
}

\author{
Priyadarshi Sharma ${ }^{1}$, Nidhi Sharma ${ }^{2}$ \\ ${ }^{1}$ Assistant Professor, Department Of TB And Chest (Respiratory Medicine), Geetanjali Medical Colege \& Hospital, Udaipur, Rajasthan, India, ${ }^{2}$ Senior Demonstrator, \\ Department Of Biochemistry ,Government Medical College ,Kota , Rajasthan, India.
}

\section{Abstract}

Background: Respiratory infections in critically ill patients are associated with high morbidity and mortality. Rapid diagnosis and initiation of appropriate antibiotic therapy is essential for better outcomes. Patients who are intubated and mechanically ventilated are further at risk of acquiring respiratory infections due to complex interplay between the endotracheal tube, host immunity and virulence of invading bacteria, which may lead to Ventilator Associated Pneumonia (VAP). Subjects and Methods: 307 total numbers of cases were included. Among all 209 cases did not develop respiratory infection \& 98 cases developed respiratory infection. This study conducted in the Department of TB \& Chest in Geetanjali Medical College, Udaipur, Rajasthan, India. The duration of study was over a period of six month. Results: In this study 307 total numbers of cases were included. Among all 209 cases did not develop respiratory infection \& 98 cases developed respiratory infection. Out of 98 cases $47.9 \%$ were male \& $52.1 \%$ were female who developed respiratory infection. In this study we suggested that $50 \%$ gram negative bacteria followed by $43.8 \%$ gram positive bacteria were found \& $6.2 \%$ fungus isolate from the 98 cases. Conclusion: This study concludes that, Culture of ET aspirate is an easy, cost-effective procedure which helps in identifying the organism. If there are any delays in antibiotic treatment, it may lead to poor outcomes.

Keywords: Endotracheal Secretions, Microbiological Profile, Isolates.

Corresponding Author: Dr. Nidhi Sharma, Senior Demonstrator, Department Of Biochemistry ,Government Medical College ,Kota , Rajasthan, India.

Received: September 2019

Accepted: September 2019

\section{Introduction}

It is certainly an irony that advanced medicine has brought a frequent botheration of nosocomial infections. The extensive use of tracheal intubation and mechanical ventilation to support critically ill has defined an increasing number of patients, at high risk of nosocomial pneumonia (NP). It has been reported that patients who are intubated and mechanically ventilated have 6 to 20 times more risk of pneumonia. ${ }^{[1]}$ In these patients, the incidence of NP has been reported to range between $9-27 \% .^{[1]}$ Ventilatorassociated pneumonia (VAP) is defined as pneumonia that develops more than 48 hours after initiation of mechanical ventilation or conceptually, as an inflammation of the lung parenchyma caused by infectious agent/s not present or incubating at the time, mechanical ventilation was started. ${ }^{[1]}$ These infections are closely related to a significant rise in morbidity and mortality. Apart from this, the emergence of multi-drug resistant (MDR) pathogens is an additional problem. Various factors like new mutations, selection of resistant strains and use of high-level antibiotics influence the rapid spread of MDR microbes in the ICU. ${ }^{[2]}$ Frequent colonization, through either endogenous or exogenous origin, has been reported in patients on mechanical ventilation with intubation. ${ }^{[3]}$

For the diagnosis of nosocomial infection, endotracheal aspiration is common in 9 ICU patients. Thus, it is recommended to the clinicians to have updated knowledge of local epidemiological and susceptibility profile for the appropriate use of antibiotics. It has become compulsory along with adequate clinical diagnosis and bacterial 10 confirmations. Therefore, the aim and objective of the present study were to analyze the microbiological profile of endotracheal secretions in patients on mechanic ventilators.

\section{Subjects and Methods}

\section{Study Population}

307 total numbers of cases were included. Among all 209 cases did not develop respiratory infection \& 98 cases developed respiratory infection.

\section{Study Area}

This study conducted in the Department of TB \& Chest in Geetanjali Medical College, Udaipur, Rajasthan, India.

\section{Study Duration}

The duration of study was over a period of six month. 


\section{Data Collection}

This cross sectional study of endotracheal secretions in patients on mechanic ventilators. The sample was sent to department of microbiology for culture and sensitivity and data were collected.

\section{$\underline{\text { Inclusion Criteria }}$}

1. Febrile illness (more than $38^{\circ} \mathrm{C}$ temperature).

\section{Exclusion Criteria}

1. Congenital anomalies of respiratory tract

2. Steroid and chemotherapy

\section{Data Analysis}

Data were analysed by using Microsoft excel.

\section{Results}

In this study 307 total numbers of cases were included. Among all 209 cases did not develop respiratory infection $\& 98$ cases developed respiratory infection. Out of 98 cases $47.9 \%$ were male \& $52.1 \%$ were female who developed respiratory infection. In this study we suggested that $50 \%$ gram negative bacteria followed by $43.8 \%$ gram positive bacteria were found \& $6.2 \%$ fungus isolate from the 98 cases, which showed in [Table 5, 6, 7]

Table 1: Distribution of gender according to developed respiratory infection.

\begin{tabular}{|l|l|l|}
\hline $\begin{array}{l}\text { Did Not Developed Respiratory } \\
\text { Infection }\end{array}$ & No. Of Cases & Percentage \\
\hline Male & 131 & $62.6 \%$ \\
\hline Female & 78 & $37.4 \%$ \\
\hline Total & 209 & $100 \%$ \\
\hline
\end{tabular}

Table 2: Distribution of gender according to developed respiratory infection.

\begin{tabular}{|l|l|l|}
\hline Developed Respiratory Infection & No. Of Cases & Percentage \\
\hline Male & 47 & $47.9 \%$ \\
\hline Female & 51 & $52.1 \%$ \\
\hline Total & 98 & $100 \%$ \\
\hline
\end{tabular}

Table 3: Distribution of cases according to clinical feature.

\begin{tabular}{|c|c|c|}
\hline Clinical Feature & $\begin{array}{l}\text { Clinical Sepsis (Who } \\
\text { Did Not Develop } \\
\text { Respiratory Infection) }\end{array}$ & $\begin{array}{l}\text { Positive Blood } \\
\text { Culture Sepsis } \\
\text { (Who Develop } \\
\text { Respiratory } \\
\text { Infection) }\end{array}$ \\
\hline $\begin{array}{l}\text { Respiratory } \\
\text { Distress }\end{array}$ & $92(44.1 \%)$ & $48(48.9 \%)$ \\
\hline Lethargy & $132(63.1 \%)$ & $62(63.2 \%)$ \\
\hline Hypothermia & $50(23.9 \%)$ & $25(25.6 \%)$ \\
\hline Hyperthermia & $19(3.1 \%)$ & $6(6.2 \%)$ \\
\hline Apnea & $26(12.5 \%)$ & $11(11.3 \%)$ \\
\hline
\end{tabular}

Table 4: Distribution of cases according to isolates.

\begin{tabular}{|l|l|l|}
\hline Isolates & No. Of Cases & Percentage \\
\hline Gram Positive Bacteria & 43 & $43.8 \%$ \\
\hline Gram Negative Bacteria & 49 & $50 \%$ \\
\hline Fungal & 6 & $6.2 \%$ \\
\hline Total & 98 & $100 \%$ \\
\hline
\end{tabular}

Table 5: Distribution of cases according to gram negative isolates

\begin{tabular}{|l|l|l|}
\hline Gram Negative Isolates & No. Of Cases & Percentage \\
\hline Klebsiella spp. & 32 & $66.7 \%$ \\
\hline E. colli & 7 & $14.3 \%$ \\
\hline Pseudomonas spp & 6 & $12.3 \%$ \\
\hline Proteus & 4 & $8.1 \%$ \\
\hline Total & 49 & $100 \%$ \\
\hline
\end{tabular}

Table 6:Distribution of cases according to gram positive isolates.

\begin{tabular}{|l|l|l|}
\hline Gram Positive Isolates & No. Of Cases & Percentage \\
\hline CONS & 18 & $41.1 \%$ \\
\hline Staphylococcus aureus & 21 & $48.8 \%$ \\
\hline Streptococcus pnemoniae & 4 & $9.3 \%$ \\
\hline Total & 43 & $100 \%$ \\
\hline
\end{tabular}

Table 7 : Distribution of cases according to fungal isolates.

\begin{tabular}{|l|l|l|}
\hline Fungal & No. Of Cases & Percentage \\
\hline Candida & 6 & $100 \%$ \\
\hline Total & 6 & $100 \%$ \\
\hline
\end{tabular}

\section{Discussion}

To prevent respiratory failure, endotracheal intubation and mechanical ventilation are life-saving procedures. Clinical conditions like a life-threatening infection, sepsis, and acute respiratory distress syndromes, neurological dysfunctions due to poisoning, drug toxicity, cerebrovascular accidents, and trauma, etc. need for ventilatory support.

Though mechanical ventilation helps to prevent deaths due to respiratory failure, yet it poses a great threat, to lifethreatening lung infections. ${ }^{[4]}$ These infections may lead to the ongoing growth of an agent that existed before intubation. Hence on the first day of intubation to identify the organisms that already existed at the time of intubation, endotracheal secretions were sent for bacteriological culture and sensitivity in the present study. It would help in initiating antibiotic therapy appropriately and in preventing the occurrence of ventilator-associated pneumonia (VAP). In this study, the most common isolate with Klebsiella was gram-negative enteric bacteria. It was the most common organism followed by Pseudomonas and Acinetobacter which were sensitive to aminoglycosides. Whereas normal lungs were found in most female patients and patients ventilated for other than respiratory causes.

A study by Ferrer et al found airway colonization by potentially pathogenic microorganisms on admission was related with failure of non-invasive ventilation for exacerbation of COPD. ${ }^{[5]}$ In contrast, in a study by Drakulovic $\mathrm{MB}$ et al found that patients admitted to a respiratory intensive care unit, initial tracheal colonization was not associated with mortality or length of stay in hospital. ${ }^{[6]}$ In another study of patients with communityacquired pneumonia, Ortqvist et al observed that respiratory tract colonization was related to a significantly increased mortality and length of stay but was not a risk factor for nosocomial pneumonia. ${ }^{[7-8]}$ Corne $\mathrm{P}$ et al studied the role of nasal carriage of staphylococcus aureus in respiratory tract infections of critically ill patients by molecular evidence. 
They revealed that $\mathrm{S}$. aureus strain isolated from nares was genetically identical to that isolated from the bronchial sample of the same patient in 15 out of 16 cases. ${ }^{\text {[9] Similar }}$ results were found by Garrouste- Orgeas $\mathrm{M}$ et al. ${ }^{[10]}$

Most of the studies showed a relationship between the organism causing VAP and pre-existing colonizing microbe. Koeman $\mathrm{M}$ et al found that topical oral decontamination with either chlorhexidine $(\mathrm{CHX}, 2 \%)$ or $\mathrm{CHX} /$ colistin $(\mathrm{CHX} / \mathrm{COL}, 2 \% / 2 \%)$ reduces the incidence of VAP. ${ }^{[11]}$

\section{Conclusion}

This study concludes that, with an empiric antibiotic treatment, de-escalation is the key to decrease the emergence of resistance. Culture of ET aspirate is an easy, cost-effective procedure which helps in identifying the organism. If there are any delays in antibiotic treatment, it may lead to poor outcomes. Inadequate and inappropriate antibiotic treatment may lead to the emergence of MDR pathogens.

Therefore, the microbiological profile \& sensitivity pattern of the local community certainly helps in framing the appropriate institutional antibiotic policy for better outcomes.

\section{References}

1. Chastre J, Fagon JY. Ventilator-associated pneumonia. Am J RespirCrit Care Med 2002;165:867-903.

2. Brusselaers $\mathrm{N}$, Vogelaers $\mathrm{D}$, Blot $\mathrm{S}$. The rising problems of antimicrobial resistance in the intensive care unit. Ann Intensive Care 2011;1:47.

3. Vadivoo NS, Santharam P, Sudha K, et al. Dynamic bacterial profile of endotracheal aspirates and its sensitivity pattern-a cause of concern. Int J Curr Res Rev 2014;6(10):112-9

4. Summaiya M and Urmi J. Assessment of biofilm formation by the causative organismsof ventilator associated pneumonia at intensive care unit of a tertiary care hospital National Journal of Medical Research 2012; 2 (1): 15.

5. Ferrer M, Ioanas M, Arancibia F, Marco MA, de la Bellacasa JP, Torres A. Microbialairway colonization is associated with noninvasive ventilation failure in exacerbation of chronic obstructive pulmonary disease. Crit Care Med 2005; 33: 2003-2009. [Pub Med: 16148472].

6. Drakulovic MB, Bauer S, Torres A, J G, MJ R, J A. Initial bacterial colonization in patients admitted to a respiratory intensive care unit: bacteriological pattern and risk factors. Respiration 2001; 68: 58- 66. [Pub Med: 11223732].

7. Ortqvist A, Hammers-Berggren S, Kalin M. Respiratory tract colonization and incidence of secondary infection during hospital treatment of community-acquired pneumonia. Eur J ClinMicrobiol Infect Dis 1990; 9: 725-731. [Pub Med: 2261917].

8. Durairaj L, Mohamad Z, Launspach JL, et al. Patterns and density of early trachealcolonization in intensive care unit patients. J Crit Care. 2009; 24(1): 114-121.

9. Corne $\mathrm{P}$, Marchandin $\mathrm{H}$, Jonquet $\mathrm{O}$, Campos J, Bañuls $\mathrm{AL}$. Molecular evidence that nasal carriage of Staphylococcus aureus plays a role in respiratory tract infections of critically ill patients. J ClinMicrobiol 2005; 43: 3491-3493.

10. Garrouste-Orgeas M, Chevret S, Arlet G, et al. Oropharyngeal or gastric colonization and nosocomial pneumonia in adult intensive care unit patients. A prospective study based on genomic DNA analysis. Am J RespirCrit Care Med 1997; 156(5): 1647-1655.

11. Koeman M, van der Ven AJ, Hak E, et al. Oral decontamination with chlorhexidinereduces the incidence of ventilator-associated pneumonia. Am J RespirCrit Care Med 2006; 173: 1348-55.

Copyright: (C) the author(s), 2019. It is an open-access article distributed under the terms of the Creative Commons Attribution License (CC BY 4.0), which permits authors to retain ownership of the copyright for their content, and allow anyone to download, reuse, reprint, modify, distribute and/or copy the content as long as the original authors and source are cited.

How to cite this article: Sharma P, Sharma N. Study on Microbiological Profile of Endotracheal Secretions in Patients on Mechanic Ventilators. Asian J. Med. Res. 2019;8(3):TB06-TB08.

DOI: dx.doi.org/10.21276/ajmr.2019.8.3.TB2

Source of Support: Nil, Conflict of Interest: None declared. 